\title{
DEAL PROTECTION MEASURES IN TAKEOVERS AND MERGERS: BREAK FEES
}

\author{
Madimetja A Lucky Phakeng \\ LLM MBL \\ Executive Director, Takeover Regulation Panel
}

\begin{abstract}
SUMMARY
This article discusses an agreement by directors to pay a break fee during a takeover or a merger and highlight some corporate governance issues that may arise due to such payments. The article further discusses how regulators limit such payments. Takeover and merger agreements contain numerous terms and conditions intended to protect all parties to the transaction. The agreements are also aimed at ensuring that, where there is a breach, the innocent party is able to recoup the costs incurred in undertaking the transaction. Break fees are some of the terms and conditions included in the takeover and merger agreements known as deal protection measures. However, these terms and conditions raise a number of concerns for shareholders, directors and regulators. They have the potential to affect the shareholders' interests negatively during a takeover or a merger. Accordingly, the Takeover Provisions set parameters within which break fees are monitored and regulated. In terms of the Takeover Provisions, the decision whether or not to agree to payment of a break fee lies with the directors of the target company. Therefore, this article is aimed at raising awareness and promoting corporate governance during takeovers and mergers.
\end{abstract}

\section{$1 \quad$ INTRODUCTION}

Takeovers and mergers of companies play an important role in the development of a country's economy. However, they also raise a number of issues for all stakeholders of the company. For the purposes of the Takeover Provisions of chapter 5 of the Companies Act 71 of $2008^{1}$ and in chapter 5 of the Companies Regulations $2011,{ }^{2}$ the impact of a takeover or a merger directly or indirectly affects various stakeholders of the company such as shareholders, directors and regulators. The term "takeover" is often used instead of "acquisition". ${ }^{3}$ The word "acquisition" is generally used to denote affected transactions as defined in Chapter XVA of the Companies Act 61 of $1973,{ }^{4}$ which is now defined in section 117 of the Act. ${ }^{5}$ In this article, for the

Hereinafter "the Act".

Hereinafter "the regulations". In this article, Chapter 5 of the Act and Chapter 5 of the Regulations are jointly referred to as the Takeover Provisions.

3 Pretorius, Delport, Havenga and Vermaas in Hahlo's South African Company Law through the Cases 6ed (1999) 568-569.

4 Ibid. 
sake of brevity, takeovers and mergers refer to the same thing. The Takeover Provisions apply to affected transactions and offers undertaken by regulated companies. ${ }^{6}$ Takeovers may be achieved by using a number of methods such as a scheme of arrangement in terms of section 114 of the Act or by means of a general offer to the shareholders of the target company. Some of the issues raised by takeovers include how best to protect shareholders without interfering with the merits of the takeover. For directors, fiduciary duties are relevant. The Act provides that the directors must act in the best interest of the company. ${ }^{8}$ The company in this respect refers to the collective shareholders of the company. ${ }^{9}$ The interests of other stakeholders such as creditors and employees are subordinate to those of shareholders. By implication, the Act rejects the pluralist approach to corporate governance. ${ }^{10}$ In principle, it is generally accepted that directors have a duty to avoid conflict interests. ${ }^{11} \mathrm{~A}$ detailed discussion relating to the fiduciary duties of directors during takeovers is beyond the scope of this article. Another issue for companies involved in a takeover is the costs of launching a takeover bid, particularly for bidders. High costs may present a stumbling block to a successful takeover. ${ }^{12}$ High costs may negatively impact on the bidders' eventual benefits to be derived from a takeover. ${ }^{13}$ In addition, the bidder, the target company, and their advisers are concerned

5 S 117 of the Act defines affected transactions as:

"(i) a transaction or series of transactions amounting to the disposal of all or the greater part of the assets or undertaking of a regulated company, as contemplated in section 112 , subject to section 118 (3);

(ii) an amalgamation or merger, as contemplated in section 113, if it involves at least one regulated company, subject to section 118 (3);

(iii) a scheme of arrangement between a regulated company and its shareholders, as contemplated in section 114, subject to section 118 (3);

(iv) the acquisition of, or announced intention to acquire, a beneficial interest in any voting securities of a regulated company to the extent and in the circumstances contemplated in section $122(1)$;

(v) the announced intention to acquire a beneficial interest in the remaining voting securities of a regulated company not already held by a person or persons acting in concert;

(vi) a mandatory offer contemplated in section 123; or

(vii) compulsory acquisition contemplated in section 124."

6 Regulated companies are determined by $s 118(1)$ as a public company, a state-owned company, unless exempted in terms of s 9 ; or a private company, but only if more than 10 per cent of the issued securities of that company that have been transferred, other than by transfer between or among related or inter-related persons, within the period of 24 months immediately before the date of a particular affected transaction or the offer exceeds 10 per cent of its issued securities or where the Memorandum of Incorporation of the private company expressly provides that the company and its securities are subject to the Takeover Provisions.

7 Luiz "Protection of Holders of Securities in the Regulated Company during Affected Transactions: General Offers and Schemes of Arrangements" 201426 SA Merc LJ 560 560.

8 Cassim "Introduction to the new Companies Act: General Overview of the Act" in Cassim (ed) Contemporary Company Law (2012) 20.

9 lbid.

10 Ibid.

1 See Cassim in Cassim Contemporary Company Law 534.

12 Jeon and Ligon "How Much is Reasonable? The Size of Termination Fees in Mergers and Acquisitions" 201117 Journal of Corporate Finance 959960.

13 Ibid. 
as to how best to execute the transaction, and ensure that the proposed transaction is consummated and completed in accordance with its terms. ${ }^{14}$ Another concern for directors is that there should be minimal disruptions to the day-to-day operations of the company. Good advisers are essential.

In order to achieve their aims, parties to a takeover may adopt numerous strategies to secure and prevent the transaction from failing. These include inserting terms in takeover agreements intended to protect the proposed transaction. This is important, taking into consideration that the costs of a takeover may still be payable even if the transaction has failed. ${ }^{15}$ The terms used to protect takeovers are referred to by a variety of names, including deal protection measures. ${ }^{16}$ Deal protection measures may assist in the success of a takeover but may also discourage a competing transaction. ${ }^{17}$ These protection measures can be classified into a few major groups. They consist of confidentiality provisions, asset lockups, no talk-, no shopprovisions, and break fees. ${ }^{18}$ Often all such terms are incorporated in the same transaction agreement. This article discusses one of the deal protection measures: break fees. Break fees are common in other countries such as the United Kingdom and Ireland. ${ }^{19}$ They are increasingly popular in the South African takeover landscape and are part and parcel of takeover transactions. ${ }^{20}$ They attract positive and negative comments. ${ }^{21}$

\section{BREAK FEES DEFINED}

Break fees are called various names such as "inducement fees" or "expense reimbursement agreement", ${ }^{22}$ "termination fees", ${ }^{23}$ "kill fees", ${ }^{24}$ and "lock up fees" ${ }^{25}$ A break fee is usually payable by the target company, whose directors have agreed to support a negotiated acquisition transaction by the bidder, to a bidder if the transaction is not implemented in accordance with the agreed terms as a result of certain clearly defined events. ${ }^{26}$ These events are usually outside the control of the bidder. The common event

14 See Jeon and Ligon 201117 Journal of Corporate Finance 959.

15 Yeung and Vincent “Delaware's 'No Go' Treatment of No Talk Provisions: Deal - Protection Devices after Omnicare" 2008 DJCL 313.

16 Clarke in Reinforcing the Market for Corporate Control (2010 UCD Working Papers in Law, Criminology and Sociology-Legal Studies Research Paper No 39/2010) http://ssrn.com abstract=1661620 (accessed 2016-05-20); also Yeung and Vincent 2008 DJCL 313.

17 Peetz "Protecting Shareholders from Themselves: How the United Kingdom's 2011 Takeover Code Amendments Hit their Mark" 2013237 Penn St JL and Int'l Aff 424.

18 Coates IV and Subramanian A Buy-Side Model of Lockups: Theory and Evidence (Harvard Law School Discussion Paper 274 2000) http://lsr.nellco.org/harvard_olin/274 (accessed 2016-05-18).

19 See Clarke in Reinforcing the Market for Corporate Control 7.

20 See Valkin and Geldenhuys "The International Comparative Legal Guide to: Mergers and Acquisitions" 2009 ICLG 268 www.iclg.co.uk (accessed 2017-07-16).

21 See Clarke in Reinforcing the Market for Corporate Control 8.

22 Clarke in Reinforcing the Market for Corporate Control 7.

23 Jeon and Ligon 201117 Journal of Corporate Finance 959.

24 Andre, Khalil and Magnan "Termination Fees in Mergers and Acquisitions: Protecting Investors or Managers?" 2007 34(3) and (4) Journal of Business Finance and Accounting 541542.

25 See Coates IV and Subramanian A Buy-Side Model of Lockups: Theory and Evidence.

26 Clarke in Reinforcing the Market for Corporate Control 7. 
triggering payment of a break fee is if the target company's board accepts another bidder's higher offer rather than the initial bid. Payment of the fee is applicable only once the board of the target company has formally agreed to proceed with the competing bid. Payment of a break fee is justified on the basis that it is compensation for the time, costs incurred and the resources expended by the bidder in pursuing and negotiating a transaction with the target. ${ }^{27}$ The usual costs include advisory fees of attorneys, accountants and other advisers. ${ }^{28}$ The reasons why the target company's board agrees to pay a break fee is that the higher offer would be to the benefit of shareholders. This will be so provided that the break fee is not very high as these can frustrate a takeover bid. ${ }^{29}$ Therefore, agreeing to pay a break fee is not necessarily prejudicial to shareholders, since the subsequent higher offer will be beneficial to shareholders. If there is no higher bid, the shareholders of the target company are in no worse position since the proposed initial transaction should proceed to completion. In some transactions, both the target company and the bidder agree to pay a break fee to each other. The bidder agrees to pay a break fee to the target company, also called a reverse break fee. The bidder will pay a fee to the target company if the bidder does not proceed with the transactions for specified reasons, such as where the shareholders of the bidder do not approve the transaction. ${ }^{30}$

\section{BREAK FEES AND TAKEOVER REGULATION}

Regulation of public takeovers raises a number of principal-agent conflicts. ${ }^{31}$ Target board members have a conflict due to the fact that a successful takeover may result in them losing their positions. ${ }^{32}$ In some cases, shareholders may wish to retain their shareholding in the existing company under the existing controlling shareholder while others may wish to sell their shares and reinvest elsewhere. Employees may be concerned with retrenchments. All these parties may wish to defend their interests for or against a takeover. This is where management of the self-interests of the various stakeholders becomes important to ensure that none of the stakeholders put their interests above others. ${ }^{33}$

The Takeover Regulation Panel ${ }^{34}$ is a statutory body established in terms of section 196 of the Act to regulate affected transactions and offers undertaken by regulated companies. Section 201 of the Act sets out the

27 Clarke in Reinforcing the Market for Corporate Control 8.

28 Che and Lewis "The Role of Lockups in Takeover Contests" 2007 38(3) RAND Journal of Economics 13.

29 See Clarke in Reinforcing the Market for Corporate Control 9.

30 United Kingdom Panel on Takeovers and Mergers Practice Statement No. 29 "Rule 21.2Offer Related Arrangements" http://www.thetakeoverpanel.org.uk/wp-content/uploads/2008 /11/PS-29-New.pdf (accessed 2016-05-15).

31 Hopt "Takeover Defenses in Europe: A Comparative, Theoretical and Policy Analysis" 2014 20(2) Columbia Journal of European Law 249251.

32 See Officer "Termination Fees in Mergers and Acquisitions" 200369 Journal of Financial Economics 431 437. See also Armour, Deakin and Konzelmann "Shareholder and the Trajectory of UK Corporate Governance" (ESRC Centre for Business Research University of Cambridge, Working Paper No. 266 2003) 4.

33 See Hopt 2014 20(2) Columbia Journal of European Law 262.

34 Hereinafter "the Panel". 
functions of the Panel, which include regulating affected transactions and offers, among other things. The mandate of the Panel is to protect minority shareholders during takeovers by fostering fairness, equity, equal treatment among shareholders, provision of relevant information, and integrity of the takeover process, among others. ${ }^{35}$ As part of enforcing its mandate, the Panel must approve circulars to shareholders that contain information relating to takeovers in terms of regulation $117 .^{36}$ The Panel also plays an important role in regulating break fees. Break fees are not applicable to all affected transactions or offers but are decided by the parties based on the type of takeover method agreed to by the parties.

The Panel regulates break fees under a broad rubric of "restrictions on frustrating action" in terms of section 126 of the Act. The section lists a number of transactions that the board of the target company may not undertake when they believe that a bona fide affected transaction or offer is imminent unless they obtain approval of shareholders and the Panel. For the purposes of break fees, it is submitted that sections 119(1)(b) and 126(1)(a) are relevant. ${ }^{37}$ Section 119(1)(b) provides that the Panel must regulate affected transactions and offers in order to prevent directors of regulated companies from taking actions "designed to impede, frustrate or defeat an offer ..." Section 126(1) in turn states that when the board of the target company believes that a bona fide offer might be imminent or has received such offer, must not take actions which could result in a bona fide offer being frustrated or the security holders of the target company being denied an opportunity to decide on the merits of the offer. These provisions are similar to those found in the United Kingdom City Code on Takeovers and Mergers ${ }^{38}$ commonly referred to as the "City Code". ${ }^{39}$ It is submitted that both sections 119(1) and 126 of the Act are aimed at deal protection measures that may negatively affect the interests of shareholders during an offer period. The offer period is defined with reference to the transaction period. ${ }^{40}$ Agreements entered into prior to the offer period that may have an impact on the takeover transaction are not automatically precluded. The board may also obtain consent from the Panel to act in accordance with the terms of such agreement where it believes that it is subject to a pre-existing

35 See $s 119(1)$ and (2), dealing with the rationale for regulating affected transactions and offers.

36 See also Luiz in "Some comments on the Scheme of Arrangements as an 'Affected Transaction"' as defined in the Companies Act 71 of 20082012 15(5) PER/PELJ 124368.

37 See Takeover Regulation Panel, Guideline 1/2012 Break Fees http://www.trpanel.co.za /index/Guidelines (accessed 2016-04-04).

38 See General Principle Number 3 of the City Code which provides " 3 . The board of an offeree company must act in the interests of the company as a whole and must not deny the holders of securities the opportunity to decide on the merits of the bid." Rule 21.1(a) of the City Code provides "During the course of an offer, or even before the date of the offer if the board of the offeree company has reason to believe that a bona fide offer might be imminent, the board must not, without the approval of the shareholders in general meeting:

(a) take any action which may result in any offer or bona fide possible offer being frustrated or in shareholders being denied the opportunity to decide on its merits or ..."

39 Clarke in Reinforcing the Market for Corporate Control 9.

$40 \mathrm{~S} 117(1)(\mathrm{g})$ defines the offer period as the time when an announcement is made or ought to have been made, of a proposed or possible offer until the first closing date or, if later, the date when the offer becomes or is declared unconditional as to acceptances or lapses. 
obligation. ${ }^{41}$ The intention of the provisions is that those transactions that have been entered into by the company in the ordinary course of business when a takeover was not contemplated by the target company should not be precluded. The Panel monitors the amount payable as a break fee relative to the value of the transaction. It has also issued a guideline on how break fees should be determined. In terms of the published guideline, a break fee payable should not be more than 1 per cent of the value of the transaction. ${ }^{42}$ This is to avoid minority shareholders being denied an opportunity to consider any higher competing takeover offer. Directors and other parties to a takeover must also disclose the existence of a break fee in the same circular that contains the details of a takeover to shareholders. ${ }^{43}$ This is in line with other international takeover regulators such as the United Kingdom Panel on Takeovers and Mergers, ${ }^{44}$ which allows an inducement fee of no more than 1 per cent of the value of the offeree company. ${ }^{45}$

Directors should not agree to pay a large amount of a break fee that could discourage other bidders and thereby prevent shareholders from considering a better takeover offer. Payment of break fees that has been appropriately capped does not prevent additional competing bidders. ${ }^{46}$ The restrictions on frustrating actions in terms of section 126 of the Act strengthen the disciplinary functions of takeovers. Self-interested directors are not at liberty to act freely and prevent a takeover. ${ }^{47}$ Researchers have made several findings of the impact of break fees on completion of takeovers. ${ }^{48}$ The amount payable as a break fee is important for a number of reasons. Allowing payment of only a small amount of a break fee may discourage bidders as such bidders may be out of pocket for costs incurred in undertaking research on the target before they launch a takeover and for other advisory costs. On the other hand, payment of large amounts may discourage competing bidders. Lower fees promote the completion of the transaction while higher fees may not be beneficial to shareholders. ${ }^{49}$ At a certain threshold, break fees lose their beneficial characteristics. Lower fees encourage a competitive bid process while larger fees discourage competing bids. ${ }^{50}$ The primary concern of regulators is that break fees may prevent a third party from making a competing bid and this may be to the detriment of shareholders of the target company. ${ }^{51}$ Some researchers who hold that management uses them to favour a selected favoured bidder also oppose deal protection measures. This is an attempt by directors to protect their future employment. In addition, it is argued that they have a potential to

41 S 126(2) of the Act.

42 See Takeover Regulation Panel, Guideline 1/2012 Break Fees http://www.trpanel.co.za/ index/Guidelines (accessed 2016-04-04).

43 lbid.

44 Hereinafter "the UK Panel".

45 See United Kingdom Panel on Takeovers and Mergers, Practice Statement No. 29.

46 Che and Lewis 2007 38(3) RAND Journal of Economics 24.

47 See Hopt $201420(2)$ Columbia Journal of European Law 281.

48 See Jeon and Ligon 201117 Journal of Corporate Finance 959-981; also Officer 200369 Journal of Financial Economics 431-467.

49 Jeon and Ligon 201117 Journal of Corporate Finance 961.

50 See Officer 200369 Journal of Financial Economics 436.

51 See United Kingdom Panel on Takeovers and Mergers, Practice Statement No. 29. 
reduce hostile offers and reduce the disciplinary effect of a takeover threat. ${ }^{52}$ While this strategy may be used by the directors, to prefer one bidder above another, it may also be used to preserve management control. ${ }^{53}$ Other practitioners prefer to characterise break fees as a contractual provision of liquidated damages. In this case, the parties agree to a pre-estimate of the loss that may occur if the agreed transaction is not completed. In this way, parties limit the break fee payable to legitimate out of pocket expenses.

In the United Kingdom, break fees are commonly referred to as inducement fees ${ }^{55}$ and are regulated as part of potential frustrating actions in terms of Rule 21 of the UK Panel City Code. ${ }^{56}$ The UK Panel seeks to ensure that shareholders are treated fair during takeovers. One of the pillars of ensuring this principle is the board neutrality rule. ${ }^{57}$ In terms of this rule, the board of directors of a target company may not take any action that may frustrate or deny shareholders the opportunity to decide on the merits of an offer themselves. There are a number of safeguards to protect shareholders to ensure that competitive takeover markets are not stifled. Following the hostile bid by Kraft Foods LLC a USA based company for the United Kingdom icon Cadbury Plc, which ended being friendly, ${ }^{58}$ the UK Panel amended a number of rules including rule 21.2 of the City Code. One of the rationales for effecting amendments was to ensure that companies do not enter into deal protection measures, which may have detrimental effects on shareholders. ${ }^{59}$ The changes to the rule introduced a prohibition of deal protection measures including inducement fees. ${ }^{60}$ However, in limited circumstances deal protection measures will be allowed. In the case of inducement fees, there is a limit that the fees should not be more than 1 per cent of the value of the target company calculated with reference to the offer price. In addition, rule 21.2 of the City Code clarifies how the fees should be calculated in cases where VAT is payable. It is suggested that the UK Panel regards the practice statement as very important as can be indicated by the detailed explanation and reasons set out in the statement. Regardless of the quantum of the break fee, the UK Panel requires the board of the target company to consult with it, at the earliest stage if a break fee is proposed. Further, the target company and its financial adviser must confirm to the Panel in writing that, the parties believe the fee to be in the best interests of the target company's shareholders, among other things. ${ }^{61}$

\footnotetext{
See Clarke in Reinforcing the Market for Corporate Control 8.

Clarke in Reinforcing the Market for Corporate Control 8.

See Curtis and Pinder "Break Fee: Where is the Harm?" 2007 14(2) Agenda 111119.

Clarke in Reinforcing the Market for Corporate Control 7.

Clarke in Reinforcing the Market for Corporate Control 9.

Peetz 2013237 Penn St JL and Int'l Aff 416.

Peetz 2013237 Penn St JL and Int'l Aff 409-412.

See United Kingdom Panel on Takeovers and Mergers, Practice Statement No. 29.

Peetz 2013237 Penn St JL and Int'l Aff 423.

See United Kingdom Panel on Takeovers and Mergers, Practice Statement No. 29.
} 


\section{DIRECTORS AND BREAK FEES}

The role and responsibilities of the board during takeovers and mergers are coming under an increasing spotlight. There are a number of debates as to what is the role and responsibilities of the board during such transactions. There are those who argue in favour of board neutrality and those who argue against it and hold that directors should be proactive during takeovers transactions. ${ }^{62}$ Directors should not frustrate takeover transactions. ${ }^{63}$ Board neutrality in the context of takeovers is accepted as part of the regulation of takeovers in South Africa. ${ }^{64}$ This is the case despite the fact that directors are also expected to act in the best interests of the company and shareholders can remove them. ${ }^{65}$ Section 126 of the Act discussed in paragraph 3 above, restricts the actions that directors may take during a takeover. This is in line with the board neutrality rule applicable in South Africa during a takeover. ${ }^{66}$ The takeover regulations create obligations for directors and assist in protecting the interests of shareholders during takeovers. These include identifying board members who may not be independent. Regulation 108(3) requires board members to declare their interests. Directors who are regarded as conflicted may not be members of the independent board committee required by regulation 108(9). This committee forms an important part of the takeover regulatory process to protect shareholders' interests during takeovers. The requirements seek to ensure that conflicts are avoided. They also seek to ensure that shareholders will receive the required information. ${ }^{67}$ The regulations aid shareholders to make informed decisions about takeovers. While the board is required to be neutral during a takeover, the regulations create certain responsibilities for the independent board. The independent board has an important role to play. ${ }^{68}$ For instance, the regulations indicate that the independent board has a responsibility for the circular to shareholders, the directors must express their opinions on the offer; ensure that they fully informed about the offer by taking steps to be informed by obtaining advice. $^{69}$

An agreement to pay a break fee may raise various concerns about the conduct of directors of target companies. This includes that directors prefer a bidder who is likely to secure their jobs. ${ }^{70}$ Some takeover agreements incorporate clauses allowing directors to enter into a break fee subject to such agreements being compliant with their fiduciary duties, commonly

62 Enriques, Gilson and Pacces "The Case for an Unbiased Takeover Law (with an Application to European Union)" 2014 Harvard Business LR 88.

Delport "Share Issues and Shareholder Protection" 2013 De Jure 1058.

64 Luiz 201426 SA Merc LJ 566.

55 Ibid.

66 The policy considerations in the Takeover Provisions in the Companies Act 71 of 2008 are the same as those in the previous Companies Act 61 of 1973. The previous Securities Regulation Code derived from the UK City Code has been re-enacted as a regulation. See Delport Henochsberg on the Companies Act 71 of 2008 (2013) 242.

67 See Regulation 106, which details the information to be provided to shareholders as part of the offer document.

68 See Luiz 201426 SA Merc LJ 567.

69 See Regulations 108-110; also Luiz 201426 SA Merc LJ 567.

70 See Clarke in Reinforcing the Market for Corporate Control 8. 
referred to as "fiduciary outs" clauses. The clauses are aimed at protecting the target company directors to act within their fiduciary duties. ${ }^{71}$ The increasing number and complexity of takeover transactions call for more diligence on the part of directors prior to entering into any takeover or merger agreement. The duties and responsibilities of directors during the life of a company are comprehensive and, in my view, are becoming more complex during takeovers. Accordingly, their discussion is beyond the scope of this note. However, the above summary highlights the important role played by directors in takeovers and any decision to pay a break fee should be considered properly.

\section{CONCLUDING REMARKS}

Payment of break fees, though not accepted by some researchers and practitioners, are widely applied to friendly transactions and have become common features in takeovers. They have a place in takeovers to protect transactions for the benefit of shareholders while at the same time protecting bidders who would be reassured to proceed with a transaction knowing that if not successful due to some specified intervening event, they will be able to recoup some of their opportunity costs incurred. It is the responsibility of the target board to ensure that bidders do not set a break fee bar so high that it may discourage competing for higher bids to the detriment of shareholders of the target company. A balance is required.

71 Gibson Dunn M and A Report 20131 www.gibsondunn.com (accessed 2016-06-30). 